\title{
Analyzing the Impact of Bapco 5 MW Solar PV Grid-Connected Project on Bahrain's Outlook for Energy-Mix Production
}

\author{
Naser Waheeb Alnaser ${ }^{1}$, Waheeb Essa Alnaser ${ }^{2}$ \\ ${ }^{1}$ Department of Architecture and Interior Design, College of Engineering, University of Bahrain, Zallaq, Kingdom of Bahrain \\ ${ }^{2}$ Department of Physics, College of Science, University of Bahrain, Zallaq, Kingdom of Bahrain \\ Email: walnaser@uob.edu.bh
}

How to cite this paper: Alnaser, N.W. and Alnaser, W.E. (2019) Analyzing the Impact of Bapco 5 MW Solar PV Grid-Connected Project on Bahrain's Outlook for Energy-Mix Production. International Journal of Modern Nonlinear Theory and Application, 8, 72-91.

https://doi.org/10.4236/ijmnta.2019.83006

Received: June 30, 2019

Accepted: August 5, 2019

Published: August 8, 2019

Copyright $\odot 2019$ by author(s) and Scientific Research Publishing Inc. This work is licensed under the Creative Commons Attribution International License (CC BY 4.0).

http://creativecommons.org/licenses/by/4.0/

\begin{abstract}
The impact of Bapco $5 \mathrm{MW}$ solar PV grid-connected project on Bahrain's outlook for clean energy and energy-mix production was analyzed since solar electricity obtained from PV installation is considered as a non-linear system. Several positive impacts were counted. These impacts were on business, economy, environment, research, green jobs creation and rooftop installation and other large-scale installation. This project had attracted public, investors, developers to invest in similar projects in the Kingdom of Bahrain; especially it is an environmentally friendly and smart technology. This innovative smart grid-connected $5 \mathrm{MW}$ solar PV power plant is enough to electrify 500 houses @ $10 \mathrm{~kW}$ and had answered lots of frustrating questions such as the effect of dust on PV performance, need of man-made cleaning compared to naturally cleaned PV panels, reliability of the system, greenhouse gases reduction and pay-back period.
\end{abstract}

\section{Keywords}

Solar PV, Bapco, 5 MW Grid Connected, Smart PV, Dust Accumulation

\section{Introduction}

Bahrain's economic was mainly on Fisheries and Pearl before Oil discovery in Bahrain in 1932; putting Bahrain as the first GCC Country to prosperous on this source of energy. In 1999, His Majesty King Hamad bin Isa Al-Khalifa became the King of Bahrain and soon he has launched Bahrain Economic Vision 2030; a vision that takes into account sustainability especially in Energy and Environment [1] [2]. The strong constitutional and vision 2030 of Bahrain lead it to 
grow and develop without ignoring the importance of clean and sustainable Energy. It was a leap to move from theoretical research on Solar Energy and other Renewable Energy assessment. The earliest published research in solar energy in Bahrain was in 1985 [3] and in assessment of renewable energy resources was in 1995 [4]. About 300 published papers were on theoretical assessment and report of small projects on solar and wind energy in Bahrain that do not exceed a capacity of $10 \mathrm{~kW}$.

In 2014, Bahrain Petroleum Company made PV Pilot project to deliver $5 \mathrm{MW}$ of distributed Photovoltaic (PV) solar systems based on technology developed by the US-based Petra Solar Inc. The project was designed, constructed, and successfully deployed to generate in excess of $8000 \mathrm{MWh}$ of clean solar energy annually. This project is expected to present an energy-offset of 67,000 million $\mathrm{ft}^{3}$ of natural gas and a savings of 6900 metric tons of carbon dioxide emissions each year.

Solar electricity from PV panels is considered as a non-linear system engineering; systems that the change of the output (solar electricity) is not proportional to the change of the input (solar radiation). This change made investors and developers are so hesitant in investing in solar energy in Bahrain due to the prevailing sky turbidity, dust and sand storms, humidity, cloud cover and effect of temperature on PV panels and resistance of the connection cables and wiring especially Bahrain is situated in an Arid Zone (longitude $50^{\circ} \mathrm{E}$ and latitude $26^{\circ} \mathrm{N}$ ) and the PV installation is the middle of a desert.

Several studies had been made in the region to study the performance of such non-linear systems (solar electricity) so the economical outcome from such systems is compared and analyzed before engaging in further investment in such technology (solar PV installation). Almarshoud [5] studied the feasibility of utilizing real time solar irradiance data for a $1 \mathrm{MW}$ grid-connected PV system in Qassim region in the middle of Saudi Arabia. An analysis has been done using both technical and economic indicators such as Yield Factor, Capacity Factor and Performance Ratio, Levelized cost of energy and payback period. Almarshoud results [5] show high energy productivity, and both technical and economic indicators are high. A $10 \mathrm{MW}$ photovoltaic grid-connected power plant commissioned at Ramagundam in India was studied whereas at this site average solar radiation about $27.3^{\circ} \mathrm{C}$ [6]. The various types of power losses such as temperature, internal network, power electronics, grid-connected, etc. as well as the performance ratio were also calculated. The final yield of plant ranged from 1.96 to $5.07 \mathrm{~h} / \mathrm{d}$, and annual performance ratio was found $86.12 \%$ while the capacity ultilzation factor was found $17.68 \%$ with annual energy generation of 15,798 $\mathrm{MWh}$, i.e. each $\mathrm{kW}$ of PV installation yield $4.3 \mathrm{kWh}$ of solar electricity per day. A further study on $5 \mathrm{MW}$ solar PV installations in India [7] shows that at various insolation levels, the load is varied and the corresponding variation in the input voltage and current to the boost converter is noted. Also, the study revealed that the changing input voltage and current follows the open circuit characteristics of the PV array closely. In Saudi Arabia, the off-grid performance of 
$5.23 \mathrm{~kW}$ Solar PV installed in 2010 at Dhahran was studied [8]. The study revealed that the hourly mean energy yield was found to be decreasing with increasing PV panel surface temperature during the months of July and August 2010 and the daily energy yield showed a decreasing trend with days of the month which could be accounted for dust accumulation on the PV panel surface. It also revealed that the DC performance ratio also showed a decreasing trend with increasing PV panel surface temperature [8].

This satisfactory outcome of this project had made a positive impact on the country policy in Renewable Energy to reduce the $\mathrm{CO}_{2}$ emission of the country and to encourage people, complexes, industries and governmental buildings in Bahrain to install PV systems on their roof as well as setting net metering to allow for feed in Tariff.

The scope of this paper is to show how this non-linear system (5 MW solar PV installation in Bahrain by Bapco to produce electricity) is successful and trustable and had made a positive impact in further use solar energy and larger future solar PV in the Kingdom of Bahrain.

\section{The Main Feature of the 5 MW Solar PV Project}

The solar installation was inaugurated in 25 June 2014 extends across the following three locations covering an area of more than $34 \mathrm{~km}^{2}$ in the Kingdom of Bahrain [9] as illustrated in Table 1.

Sadeem building or Transport building is an additional extension of Bapco PV project to study the performance of $8.64 \mathrm{~kW}$ PV panels on rooftop (or retrofit), i.e. it is the first BIPV in Awali Town, Bahrain. It consists of 36 panels on the roof each has $240 \mathrm{Wp}$. The panel's orientation is $225^{\circ}$ from the north. Panels have tilt of $25^{\circ}$ although the latitude of Bahrain is $26.13^{\circ} \mathrm{N}$ and latitude $50.8^{\circ} \mathrm{E}$. The total area of PV panels on the roof is about $60 \mathrm{~m}^{2}$.

Bapco PV Project is part of Bahrain's government ongoing efforts to support and implement national initiatives of the Kingdom and in collaboration with the National Oil and Gas Authority (NOGA). Bapco has adopted an initiative to enhance the improvement of the clean energy generation file through the application of solar energy technologies. The project contributes to the establishment

Table 1. The distribution of Bapco 5 MW PV installation in Bahrain.

\begin{tabular}{lcc}
\hline \multicolumn{1}{c}{ Site Name } & Installation Type & Installation Size \\
\hline 1) Awali Town & Carports & $1.51 \mathrm{MW}$ \\
& Solar Trees & $240 \mathrm{~kW}$ \\
& Street Light Poles & $48 \mathrm{~kW}$ \\
2) University of Bahrain & Ground Mount & $501 \mathrm{~kW}$ \\
3) Refinery & Car Ports & $2.7 \mathrm{MW}$ \\
TOTAL & & $5.0 \mathrm{MW}$ \\
4) Sadeem Building & $\begin{array}{r}\text { 36 panels on the roof @ } 240 \mathrm{Wp} . \\
\text { PV panels at direction } 225^{\circ}\end{array}$ & $8.64 \mathrm{~kW}$ \\
& from the north with $25^{\circ}$ tilt angle. & \\
\hline
\end{tabular}


of renewed energy industries as part of the national economy in the future, in addition to the creation of job opportunities and a new industry at the domestic market. It also aims to reduce reliance on natural gas.

Figures 1-6 illustrate this PV installation on different parts; it was an attraction and wonder to citizens and policy makers and had inspired policy makers, researchers and developer to further think about solar energy and renewable energy utility.

BAPCO PV installations utilize one of the industry's most advanced micro-inverter technologies to create a wireless smart-grid network, providing critical system-wide intelligent monitoring and control. These advanced technologies enable the highest levels of overall system uptime, performance, and yield, throughout its lifespan of over 25 years. In fact, Bahrain is the first country in the MENA region to integrate and monitor a highly distributed system into a single PV power plant! Figure 7 illustrates how the PV electricity is transferred to the national grid in Bapco $5 \mathrm{MW}$ PV project [10].

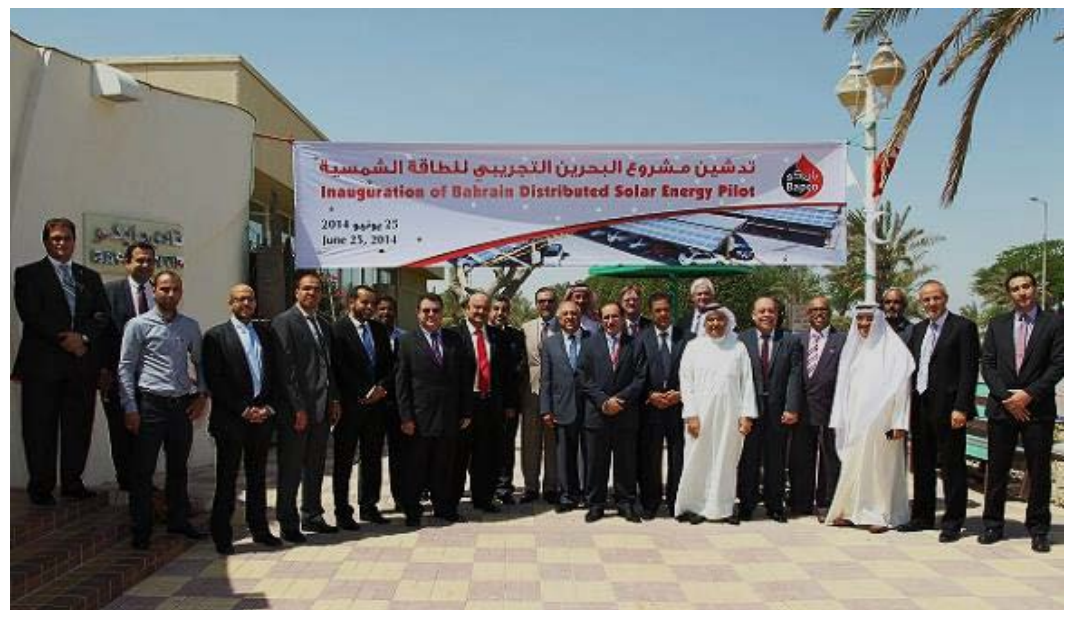

Figure 1. Top officials in the inauguration of the Bahrain Solar Energy Pilot Project (5 MW) by Bapco on Wednesday, June 25, 2014.

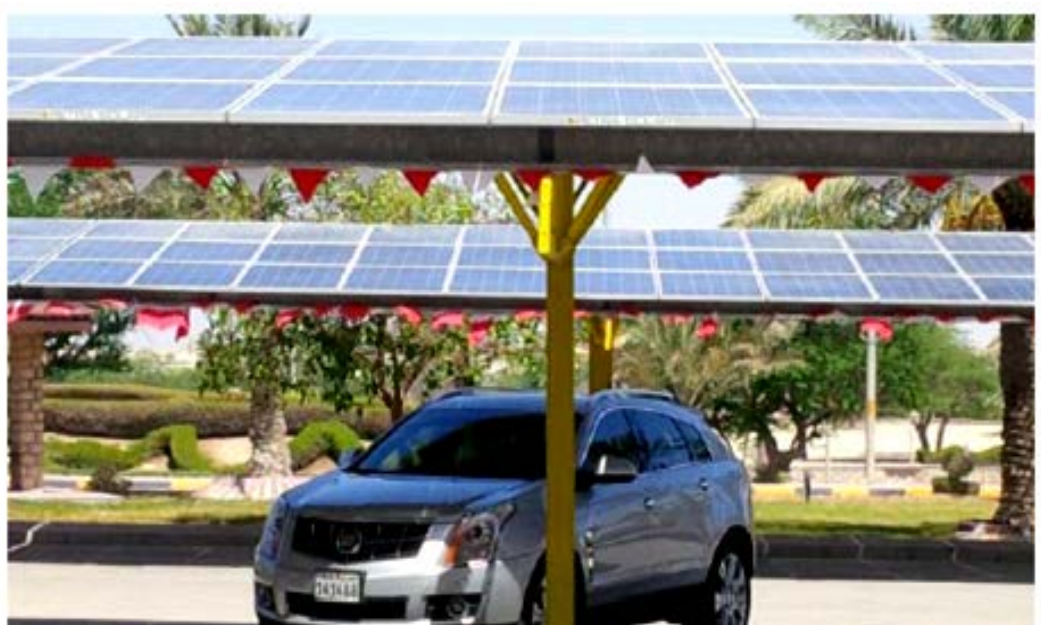

Figure 2. PV panels mounted on carports in Awali town, Kingdom of Bahrain. 

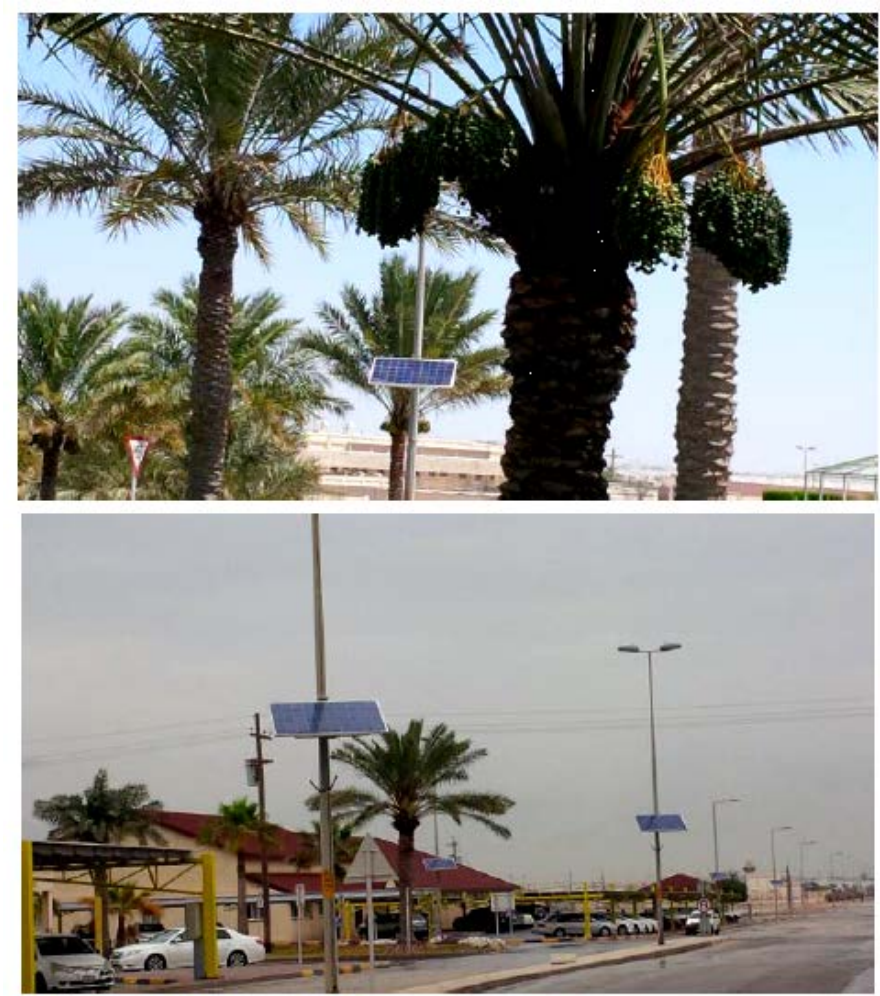

Figure 3. PV panels mounted on street light poles in Awali town, Kingdom of Bahrain.
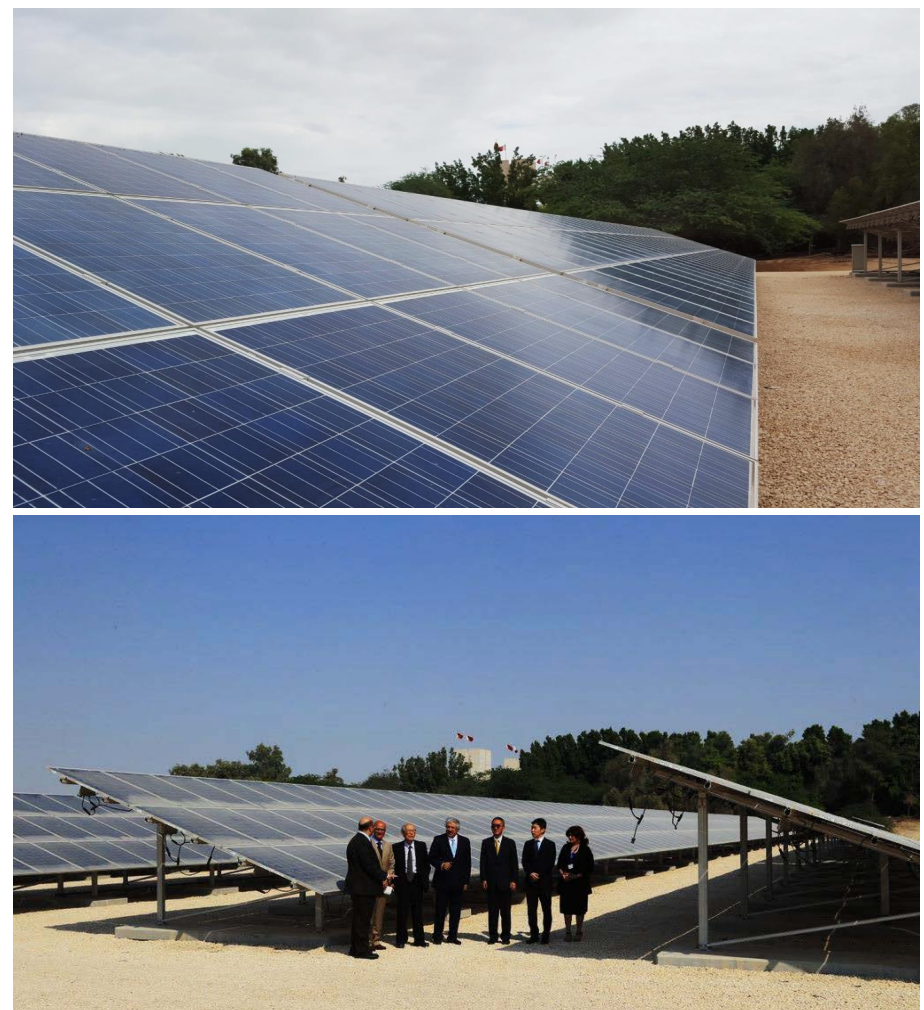

Figure 4. The $0.518 \mathrm{MW}$ solar pv polycrystalline photovoltaic ground-mounted, solar-grid modules deployed at the University of Bahrain-Part of 5 MW BAPCO pilot Project in the Kingdom of Bahrain. 


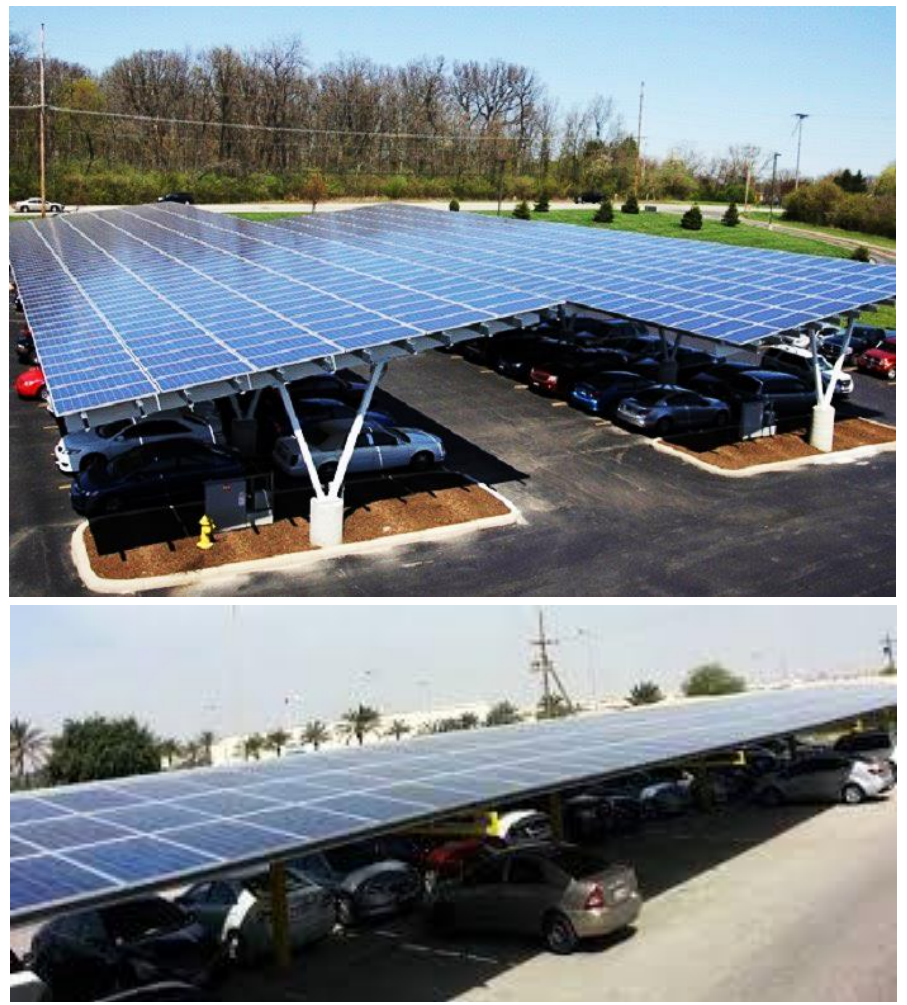

Figure 5. The refinery 2.7 MW car ports solar PV polycrystalline connected to national grid-Part of 5 MW BAPCO pilot project in the Kingdom of Bahrain.


Figure 6. Sadeem Building: First BIPV in Bahrain at Bapco, Awali Town, $8.64 \mathrm{~kW}$. It consists of 36 panels on the roof each has $240 \mathrm{Wp}$. The panel's orientation is $225^{\circ}$ from the North. The PV panels have tilt angle of $25^{\circ}$. The total area of PV panels on the roof is about $60 \mathrm{~m}^{2}$. Note that the latitude of Bahrain is $26.13^{\circ} \mathrm{N}$ and the longitude is $50.8^{\circ} \mathrm{E}$. 


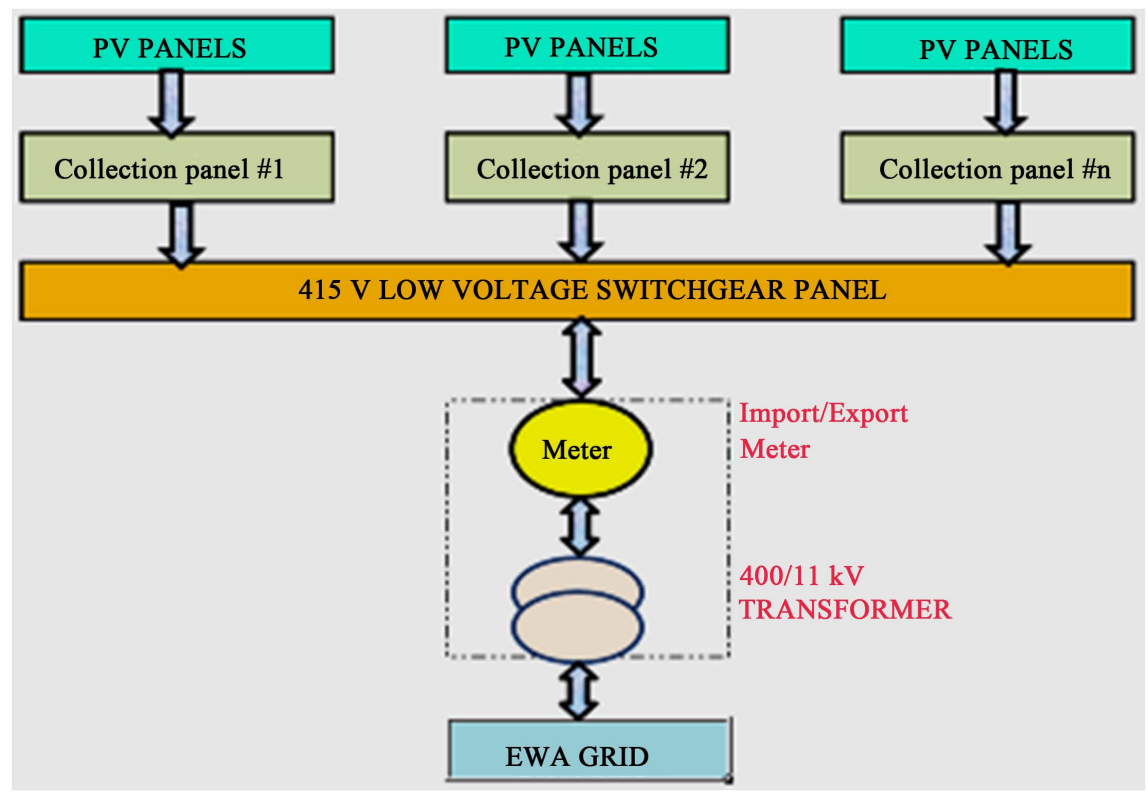

Figure 7. Illustrates how the PV electricity in this project is transferred to the national grid. It is the solar Schematic diagram.

\section{Impact of Bapco 5 MW Solar PV Project on Bahrain's Economy, Business, Environment and Policy}

This project had made positive contribution to the policy, development, economy, environmental and business in the Kingdom of Bahrain. Herein, a highlight on such positive impact in the Kingdom of Bahrain is discussed.

\subsection{Scientifics Lessons Learnt}

It was a fortune to obtain automated reliable results locations for certain years as some of MCCB failure results in disconnection of PV panels to the grid. There was a concern on Sadeem Building recorded data; therefore, it was adjusted to become more sensible. Table 2 displayed the solar PV yield from the 4 sites of the project listed in Table 1.

The Expected solar electricity in Table 2 is based on Solar Home design Manual Shawna Henderson and Don Roscoe [11]. This means that the expected solar energy for Bahrain environment shall be $1477 \mathrm{kWh} / \mathrm{kW} /$ year $(1 \mathrm{~kW}$ yield yearly $1477 \mathrm{kWh}$ or $1 \mathrm{~kW}=4.1 \mathrm{kWh}$ daily). Hence, for example, expected energy for the $518 \mathrm{~kW}$ PV system at University of Bahrain (UoB) facility for one year is $1600 \times 518 \mathrm{~kW}=764,950 \mathrm{kWh}$. The actual solar electricity actually recorded at UoB in 2014 was 718,563 kWh, in 2015 it was 795,158 kWh and in 2016 it was $711,814 \mathrm{kWh}$. However, if we use Alnaser's estimation [12] then the expected annual solar electricity from UoB solar PV field will be 984,120 kWh which means $1898 \mathrm{kWh} / \mathrm{kW}$ ( $1 \mathrm{~kW}$ yield yearly $898 \mathrm{kWh}$ or $1 \mathrm{~kW}=5.2 \mathrm{kWh}$ daily)! This means that the expected yield from ref [11] is more sensible than from ref. [12].

Figures 8-11 display the correlation coefficient between the expected and 


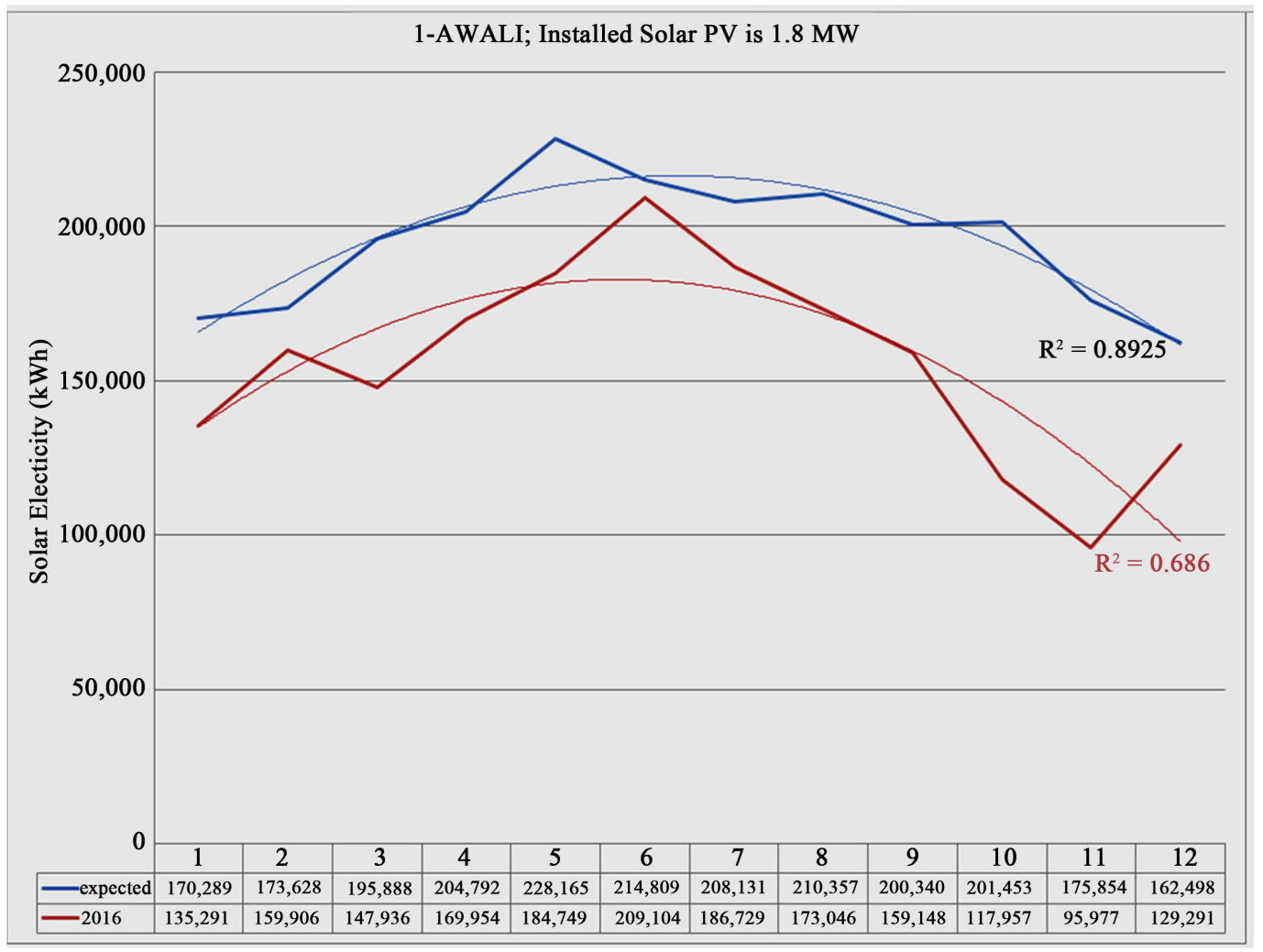

Figure 8. The correlation coefficient between the expected and actually measured data in 2016 for Awali Site.

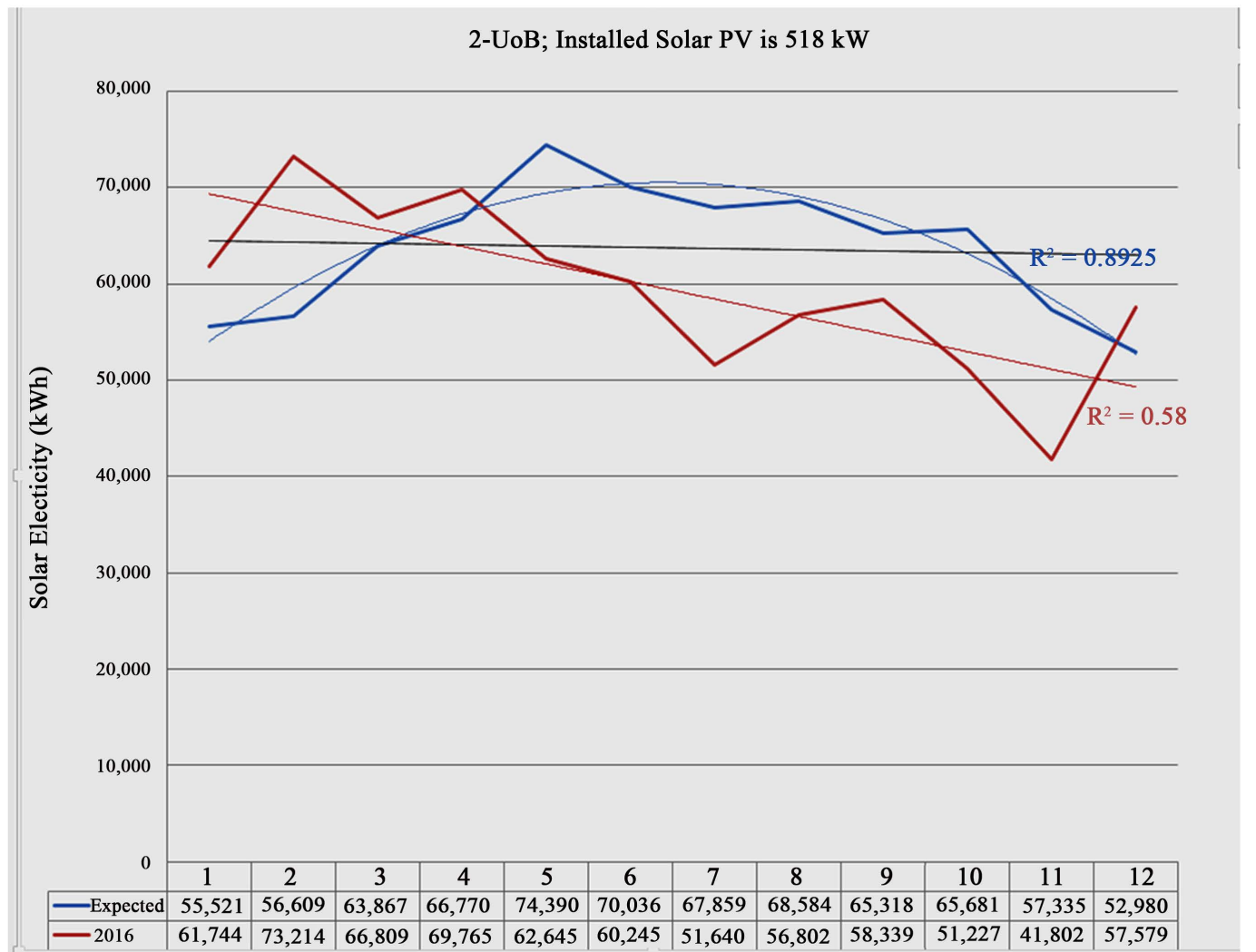

Figure 9. The correlation coefficient between the expected and actually measured data in 2016 for University of Bahrain Site. 




Figure 10. The correlation coefficient between the expected and actually measured data in 2016 for Refinery Carport Site.

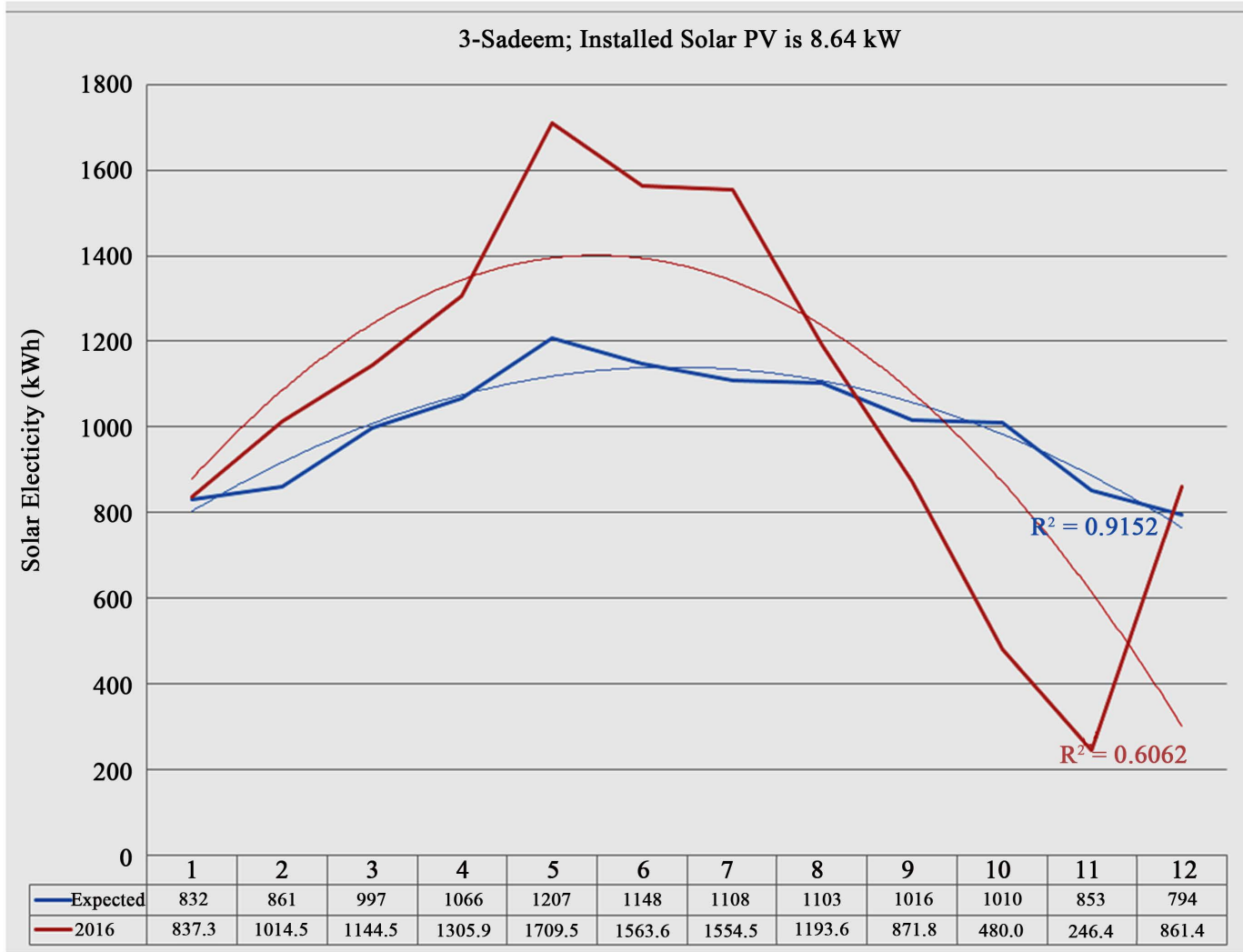

Figure 11. The correlation coefficient between the expected and actually measured data in 2016 for Sadeem building Site. 
Table 2. Displayed the solar PV yield from the 4 sites of the 5 MW PV Bapco project in the Kingdom of Bahrain.

\begin{tabular}{|c|c|c|c|c|c|c|c|c|c|c|c|c|c|c|c|}
\hline Area/Month & Year & Jan & Feb & March & April & May & June & July & Aug & Sept & Oct & Nov & Dec & Total & $\mathrm{kW} /$ day \\
\hline 1) UoB & $\begin{array}{c}\text { Expected } \\
(\mathrm{KWh})\end{array}$ & 55,521 & 56,609 & 63,867 & 66,770 & 74,390 & 70,036 & 67,859 & 68,584 & 65,318 & 65,681 & 57,335 & 52,980 & 764,950 & 4.09 \\
\hline $\begin{array}{l}\text { Capacity = } \\
0.518 \text { MW }\end{array}$ & 2014 & 77,590 & 64,321 & 58,735 & 47,296 & 58,598 & 67,316 & 57,420 & 43,306 & 45,848 & 69,907 & 59,327 & 66,899 & 718,563 & 3.97 \\
\hline$\# P V=2160$ & 2015 & 66,287 & 62,536 & 64,334 & 27,310 & 57,826 & 59,559 & 57,671 & 46,058 & 59,233 & 93,337 & 53,086 & 47,920 & 795,158 & 3.63 \\
\hline$A=3521 \mathrm{~m}^{2}$ & 2016 & 61,744 & 73,214 & 66,809 & 69,765 & 62,645 & 60,245 & 51,640 & 56,802 & 58,339 & 51,227 & 41,802 & 57,579 & 711,814 & 4.40 \\
\hline 2) REFINERY & $\begin{array}{c}\text { Expected } \\
(\mathrm{KWh})\end{array}$ & 309,733 & 315,806 & 356,294 & 372,490 & 415,002 & 390,709 & 378,563 & 382,612 & 364,392 & 366,416 & 319,855 & 295,562 & $4,267,434$ & 4.09 \\
\hline $\begin{array}{c}\text { Capacity }= \\
2.892 \mathrm{MW}^{\#} \\
\mathrm{PV}=12,050 \\
\mathrm{~A}=19,642 \mathrm{~m}^{2}\end{array}$ & 2016 & 263,874 & 325,629 & 329,645 & 353,979 & 390,536 & 339,653 & 379,471 & 324,342 & 323,077 & 215,551 & 130,697 & 187,148 & $3,563,602$ & 4.19 \\
\hline 3) AWALI & $\begin{array}{c}\text { Expected } \\
(\mathrm{KWh})\end{array}$ & 170,289 & 173,628 & 195,888 & 204,792 & 228,165 & 214,809 & 208,131 & 210,357 & 200,340 & 201,453 & 175,854 & 162,498 & $2,346,204$ & 4.09 \\
\hline $\begin{array}{c}\text { Capacity }= \\
1.590 \mathrm{MW}^{\#} \\
\mathrm{PV}=6625 \\
\mathrm{~A}=10,799 \mathrm{~m}^{2}\end{array}$ & 2016 & 135,291 & 159,906 & 147,936 & 169,954 & 184,749 & 209,104 & 186,729 & 173,046 & 159,148 & 117,957 & 95,977 & 129,291 & $1,869,088$ & 3.60 \\
\hline 4) Sadeem Building & $\begin{array}{c}\text { Expected } \\
\text { (Kwh) }\end{array}$ & 832 & 861 & 997 & 1066 & 1207 & 1148 & 1108 & 1103 & 1016 & 1010 & 853 & 794 & 11,996 & 3.88 \\
\hline $\begin{array}{c}\text { Capacity }=8.64 \mathrm{~kW}^{*} \\
\mathrm{PV}=36 \\
\mathrm{~A}=64.8 \mathrm{~m}^{2}\end{array}$ & 2016 & 837.3 & 1014.5 & 1144.5 & 1305.9 & 1709.5 & 1563.6 & 1554.5 & 1193.6 & 871.8 & 480.0 & 246.4 & 861.4 & 12,783 & 5.15 \\
\hline
\end{tabular}

actually measured data in 2016 for the 4 Sites of the distributed 5 MW Solar PV project. We have chosen 2016 as it is the most accurate recorded results. The correction coefficient $\left(\mathrm{R}^{2}\right)$ indicates how the sunshine is actually steady or interrupted by dust, clouds, haze, humidity, invertor performance, and temperature effect on PV performance [13]. Low $\mathrm{R}^{2}$ means your expected income or yield from solar electivity will n0t be accurate. The customer or developer may be disappointed when he found the payback period becomes much larger than its planed! The figures show that best correction was 0.83 (Refinery Site) and the least was 0.58 at $\mathrm{UoB}$ site. For the expected solar electricity the value of $\mathrm{R}^{2}$ is always near 0.9 .

What is interesting in this table is the last column which leads to an experimental result indicating that $1 \mathrm{~kW}$ of solar installation will give daily solar electricity in Bahrain equal to $4.1 \mathrm{kWh}$ or $125 \mathrm{kWh}$ monthly or $1517 \mathrm{kWh}$ annually. That was an important finding for consumer and providers in putting a tariff for feeding the solar electricity to the grid. Currently, the government of Bahrain through Electricity and Water authority had allowed special facility for roof top Solar PV installation which is for a size of $7 \mathrm{~kW}$ at a cost of BD 3500. This full 7 $\mathrm{kW}$ photovoltaic system the customer will pay USD 9100 (PV panels plus invertors and charge regulators). If the government purchase each $\mathrm{kWh}$ at a cost of $1 \mathrm{c} \$$ ( 3 fils) then the payback period (PBP) will be 118 years, while if the tariff is purchased at a cost of $26 \mathrm{c} \$$ (100 fils) - if Feed-In-Tariff is initiated-the PBP 
will be 4.6 years [14]; more accurate calculation of PBP is available elsewhere [15]. Also, this figure ( $1 \mathrm{~kW}$ yield $125 \mathrm{kWh}$ per month ) is important for net metering because each household will realize that if he installed $7 \mathrm{~kW}$ on his house rooftop he will be able to generate monthly solar electricity of no more than $890 \mathrm{kWh}$ per month. This production of solar electricity will financially waive only BD25 (USD 68) from his monthly electricity consumption which no less than $3000 \mathrm{kWh}$, in average, in Bahrain as electricity consumption per capita per year is $17,493 \mathrm{kWh}$ or $1457 \mathrm{kWh}$ per month [16].

\subsection{Effect of Dust and Its Economic Impact}

One of the major reasons for the poor performance of PV systems in the MENA region is dust accumulation. Unlike concentrated solar power (CSP), poly-crystalline and single-crystalline PV panels have shown power reduction in excess of $60 \%$ due to dust particles.

This project (the Bapco $5 \mathrm{MW}$ solar PV) had allowed researchers to study the effect of dust on PV performance in Bahrain [17]. The study was based on eight PV panels out of an array of $2088 \mathrm{PV}$ panels forming the $500 \mathrm{~kW}$ system. The eight panels under study were not been cleaned since October 1, 2013. The density of the accumulated dust ranged from 5 to $12 \mathrm{~g} / \mathrm{m}^{2}$ with an average PV power drop to $40 \%$ of the maximum available. The collected dust was analyzed revealing that the main elemental contents were $\mathrm{Si}(\sim 15 \%)$ and $\mathrm{Ca}(\sim 15 \%)$ in addition to $\mathrm{Al}(\sim 6 \%), \mathrm{Mg}(\sim 5 \%)$, and $\mathrm{Fe}(\sim 5 \%)$. Finally, two important empirical equations were established that allowed the estimation of the loss in light transmissivity (in \%) due to dust accumulation $\left(\mathrm{g} / \mathrm{m}^{2}\right)$ on the PV panels, as well as a drop in PV power output as a result of dust density.

In this project, two sets of $\mathrm{PV}$ panels-each set consist of 8 panels. One set was cleaned two times in one year and the other was set naturally, i.e. naturally cleaning [17]. The accumulation of dust on PV panels became more significant in August and September due to humid weather during these two months with less wind speed that contributed to the adhesion (sticking) of dust on the panels, leading to loss of solar electricity production. This is apparent by the drop in the expected generated power ranging from $14.1 \%$ to $24.9 \%$ in August and from $21.6 \%$ to $32.5 \%$ in September.

The effect of dust on the performance on the two sets of PV panels was found to be less serious than expected! The maximum monthly average drop in the expected PV output did not exceed $32.5 \%$, and in a single day, it did not exceed $50 \%$, before the panels had been cleaned even after seven months of installation. On the contrary, the panels were found to produce more solar electricity than the expected monthly average of $26 \%$, and on some days up to $50 \%$, after cleaning. The overall performance of these panels in a 9-month period (Feb to Nov., 2014) was found to be greater than expected by $5.1 \%$ (Panel CP8) and less than expected by $4.8 \%$ (Panel CP2).

What is more interesting is our finding that on the $2^{\text {nd }}$ of April 2015 a heavy dust storm had hit Bahrain. The PV panels at UoB Site in this Bapco 5 MW 
project were covered by about $2 \mathrm{~mm}$ of Dust (Figure 12). Surprisingly, the solar electricity from UoB panels was not zero in this day but $25 \%$ of the expected yield (a daily of $2330 \mathrm{kWh}$ for installation of about $518 \mathrm{~kW}$ ) which is about 580 $\mathrm{kWh}$ !

On contrary, on the $28^{\text {th }}$ of Nov. 2014 there was a heavy rain in Bahrain (Figure 13). The PV panels were cleaned naturally-saving a lot of water and man-power. The solar electricity from UoB panels was slightly more than the expected in this day by $10 \%$, i.e. an extra energy of $233 \mathrm{kWh}$.

The finding of our work on the effect of dust deposition of the dust on the surface of the photovoltaic solar modules [17] is in agreement with a reported



Figure 12. About $2 \mathrm{~mm}$ of Dust had resulted from a heavy dust storm hit Bahrain in 2 April 2015. Surprisingly, the solar electricity yield in this day was $25 \%$ of the expected yield, i.e. a yield of $580 \mathrm{kWh}$ !

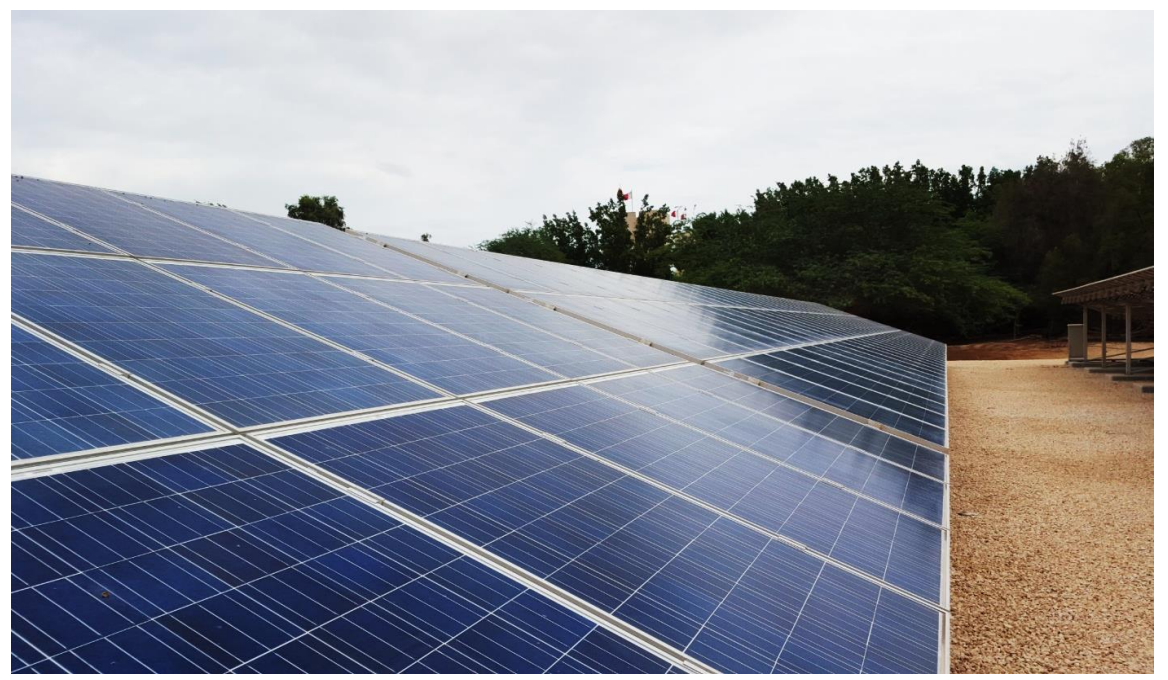

Figure 13. On the 28th of Nov. 2014 there was a heavy rain in Bahrain. The PV panels were cleaned naturally. The solar electricity from UoB panels was slightly more than the expected in this day by $10 \%$, i.e. an extra of $233 \mathrm{kWh}$ solar electricity. 
work from Iraq [18] where they reported a reduction in both the short circuit current $\left(\mathrm{I}_{\mathrm{sc}}\right)$ and the output power compared to the same parameters of the clean module. The average degradation rate of the efficiencies of the solar PV modules due to exposed to dust is $6.24 \%, 11.8 \%$ and $18.74 \%$ calculated for exposure periods of one day, one week and one month.

\subsection{Effect of Using Smart Energy Module on Inspiring IT and EE Researchers}

In this Bapco 5 MW PV project, the Petra Solar's Sun Wave was used which offered an advanced architecture providing two-way communications with each AC module (i.e. a Solar Panel plus Smart Energy Module, or SEM) for individual monitoring and control. This system enables the remote management of a large, geographically dispersed AC module population from a single, centralized location. A typical communications system, illustrated in Figure 14, comprises multiple AC modules, a communicator, and Intelli View.

Each Smart Energy Module (SEM) has a built-in revenue grade energy generation metering that measures the energy output to the electric grid and every SEM within the network is equipped with its own communication system. Using the Zigbee $\mathrm{PRO}^{\oplus}$ protocol standard, SEMs periodically transmit their measurement data to their local communicator. The communicator collects this data and periodically sends the aggregated SEM data to the Data Center over the local mobile communications network (e.g., GSM or CDMA), using the HTTP protocol.

The communications between the AC modules and the Data Center is bidirectional, so in addition to the measurement data being pushed to (or pulled from) the Data Center, the Data Center also has the ability to issue commands to each of the AC Modules, thus providing complete control of each device. It is part of a Smart Grid Networks.

The smart Grid Network (this Bapco 5 MW solar PV project) is a collection of AC modules connected by a single, common communication channel represents a local Smart Grid Network, which allows information to be exchanged between

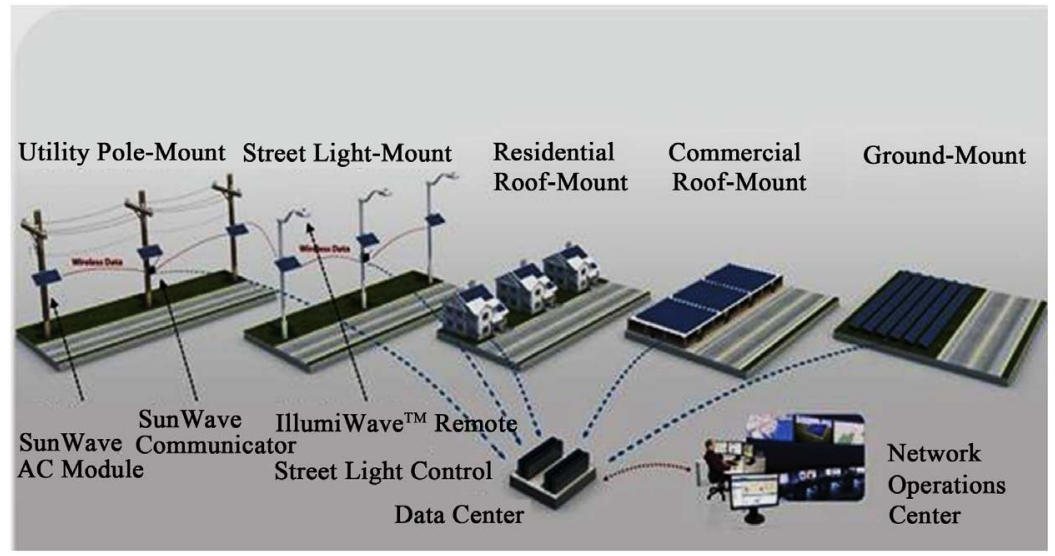

Figure 14. Typical communications system. 
the AC modules and the Data Center. Each network covers a specific geographic area and provides information about where the associated communicator is located, and which AC modules are expected to connect to the associated communicator. Figure 15 illustrates a typical network architecture design [17].

This project has inspired lots of Information Technology and Electrical and Electronic Engineering students in Bahrain and in the region to conduct research, projects, workshops and seminars at UoB and other private and governmental universities in Bahrain and neighborhood as well as units in government like Sustainable Energy Unit at Electricity and Water Authority in Bahrain [19] [20] [21].

\subsection{Effect on Business and Green Job Opportunity}

With the successful Bapco 5 MW solar PV project, many developers and investors found necessary to invest in renewable and solar energy.

In October 2016, the Sustainable Energy Unit (SEU) had finalized the preparation of Bahrain's first National Renewable Energy Action Plan (NREAP), which identifies feasible renewable energy options for Bahrain, sets the targets, and proposes policies and initiatives to achieve the targets [22]. NREAP represents the Kingdom's efforts to deliver the sustainable energy transition envisioned in the Economic Vision 2030. The Plan sets a national renewable energy target of $5 \%$ by 2025 and $10 \%$ by 2035 . The proposed renewable energy-mix consists of solar, wind and waste to energy technologies.

Under these circumstances, Bahrain's drive to promote clean renewable energy solutions for sustainable development and environmental protection is highly commendable. Here are some interesting and important energy-related facts about Bahrain:

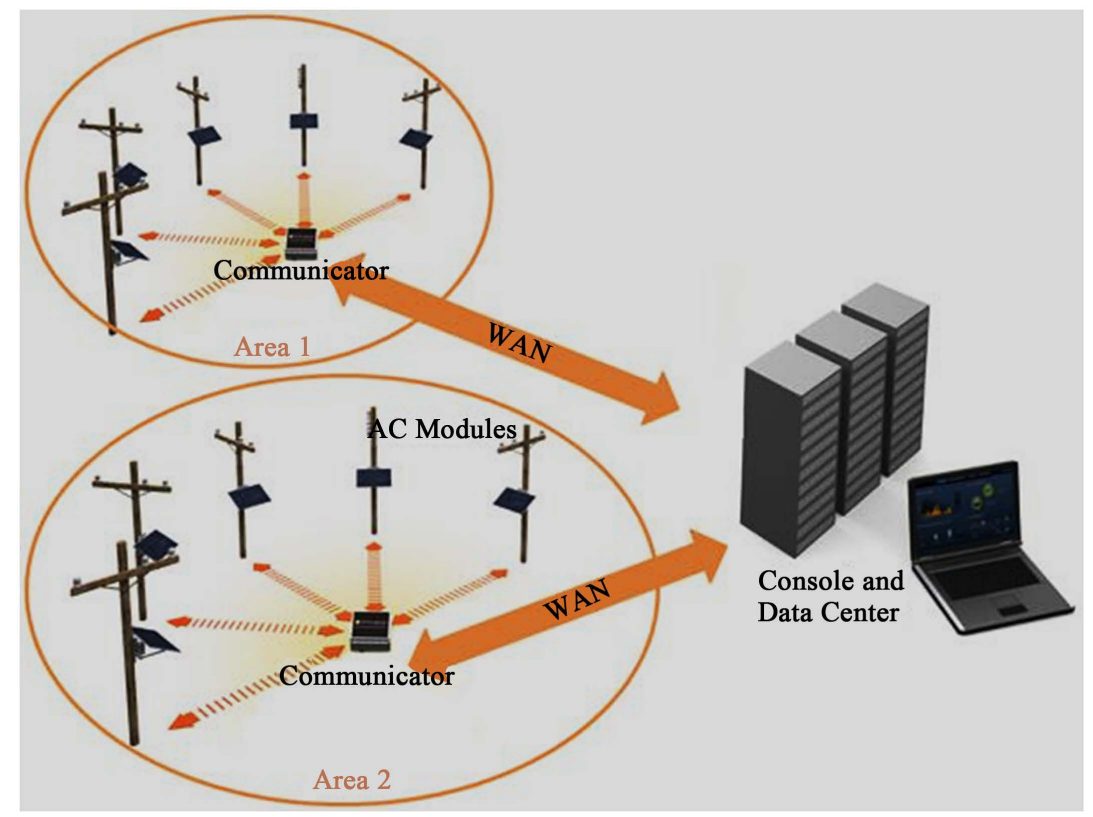

Figure 15. Typical network architecture design. 
- The total installed electricity capacity in 2018 is about $3.6 \mathrm{GW}$, all coming from natural gas. Therefore, diversity or energy mix is important for energy security.

- In 2018, Bahrain had generated 17,000 GWh of electricity and it is expected to generate more in future.

- Its gas reserves should last about 50 years at present rates of consumption with the risk that it is only enough to meet current demand up to year 2018!

- Bahrain's per capita energy consumption, which is among the highest in the world, has nearly doubled during the last decade and with an annual increase of $10 \%$, it is expected to reach $4803 \mathrm{MW}$ in 2020 .

Now, if Bahrain target is to have $5 \%$ solar by 2025 , i.e. say $5 \%$ out $4 \mathrm{GW}$ which is $200 \mathrm{MW}$ solar PV in about 6 years, then this means that Bahrain needs to purchase $33 \mathrm{MW}$ per year requiring annual production of 100,000 PV @ $330 \mathrm{~W}$ or $280 \mathrm{PV}$ panels daily with non-stop factory operation of PV! Such demand will allow for green-job opportunities besides the need for establishing maintenance and energy savings companies (ESC).

First positive impact of the successful Bapco Project is the establishment of Solar One Company. It is Bahrain's first solar panel manufacturing facility. Its mission is to produce high-quality solar panels using state of the art technology to provide clean, free energy for everyone.

The company has a great chance to lead the way in the renewable energy industry in the Middle East, and help steer the region towards meeting and exceeding its climate goals.

The company manufacturing capacity is 60,000 panels per year. This is equal to producing $15 \mathrm{MW}$ of power. The prices of the PV panels are comparable to those available in China or India, without the import cost. Solar One is positioned to anticipate and facilitate a shift towards renewable energy [23].

An up-to-date review of the progress made on solar energy in the GCC Countries, together with the challenges and barriers hindering the development of Renewable Energy in these countries in technology, policy development, and insufficient application of RE technology integrated to the buildings and how successful projects could contribute to overcome such barriers, is explained in detail elsewhere [24].

\subsection{Effect on the Increase of Roof-Top PV Installation}

One of the most important fruits of Bapco $5 \mathrm{MW}$ solar PV project is the wide spread of installation of PV systems on a rooftop-making the building integrated with Photovoltaic BIPV-for power up to $7 \mathrm{~kW}$ at relatively low cost (BD 3500 or US\$ 9100). This can be further spread if the government of Bahrain offers more incentives that were explained elsewhere [14].

In the past two years, several large-scale rooftops were made in Bahrain after people had learnt from Bapco Solar PV project. This includes installation 3.1 MW at King Hamad University Hospital roof top, $250 \mathrm{~kW}$ at Avenue Mall Building, $90 \mathrm{~kW}$ at Islamic Awqaf (Endowment), and several household houses 
in Northern Area and Khalifa Town.

Retrofitting the older buildings-due to the weight of these solar PV panels which weigh about $16 \mathrm{~kg} / \mathrm{m}^{2}$ - will further boost this roof-top application. The newer technology, provide solar panels around $3-4 / \mathrm{m}^{2}$ [25], which means that we can probably fit it on to the old canopies because the canopies are civil structures which need to carry the panel's weight about 10 plus $\mathrm{kg}$ per $\mathrm{m}^{2}$; lighter panels is much easier for us to do the retrofitting.

\subsection{Impact on Reducing $\mathrm{CO}_{2}$ Emission}

In recent years, Bahrain has faced challenges brought on by climate change, and have therefore been obliged to devise plans that include projects to address these challenges. Bahrain is perhaps the most vulnerable to the threat of rising sea levels because of its location in a low-lying coastal zone, where most of its population and industries reside. According to Bahrain's Second National Communication [26], the current built-up and industrial areas in Bahrain account for about $300 \mathrm{~km}^{2}$ of a total land area of $748 \mathrm{~km}^{2}$ (about $40 \%$ ), and are located largely along the eastern coastline of Bahrain's main island. The study shows that $11 \%\left(83 \mathrm{~km}^{2}\right)$ of total Bahraini land will be inundated by 2050 if the sea level rises by $0.3 \mathrm{~m}$ and $27 \%\left(200 \mathrm{~km}^{2}\right)$ by 2100 if the sea level rises by $1.5 \mathrm{~m}$. This is the expected scenario if there is no accelerated deglaciation. However, in the case of extreme deglaciation, 27\% (199 $\left.\mathrm{km}^{2}\right)$ of Bahrain's land will be inundated by 2050 if the sea level rises by $1 \mathrm{~m}$ and $56 \%\left(418 \mathrm{~km}^{2}\right)$ of the land faces inundation by 2100 if the sea level rises by $5 \mathrm{~m}$.

It is also expected that the climate change impact will lead to temperature rise and drought cycles, resulting in more frequent dust storms, which exacerbate air pollution and soil erosion. In 2006, Bahrain's GHG emissions stand at an annual total of 29 million ton of $\mathrm{CO}_{2}$ equivalent to about 28 tons per capita while in 2015 the emission reached 40 million ton and to about 33 tons per capita. The sources of more than $87 \%$ of GHG emissions come from energy-related sub-sectors, making Bahrain the second highest in the GCC after Saudi Arabia [27] [28]. More than half the electricity generated ( $56 \%)$ is consumed by the residential sector in Bahrain, producing $20 \%$ of the Kingdom's total $\mathrm{CO}_{2}$ emissions.

In an effort to change the status quo, Bahrain's political and economic leadership has wisely formulated its energy strategy to reduce $\mathrm{CO}_{2}$ emissions by investing in the renewable energy sector.

The installation of $5 \mathrm{MW}$ solar PV in Bahrain in 2014 had allowed for an annual reduction of $\mathrm{CO}_{2}$ (Green House Gases) by about 8000 tons annually-assuming each $1 \mathrm{kWh}$ from natural gas emits $1 \mathrm{~kg}$ of $\mathrm{CO}_{2}$. This means that if every year Bahrain install $33 \mathrm{MW}$ to meet its target by 2025 (5\% solar or renewable energy from $4 \mathrm{GW}$ national power capacity) then this will lead to an annual reduction of 56,000 tones, 108,400 tones, 168,000 tones, 224,000 tones,280,000 tones, and 336,000 tones in years 2020, 2021, 2022, 2023, 2024 and 2025, respectively. 


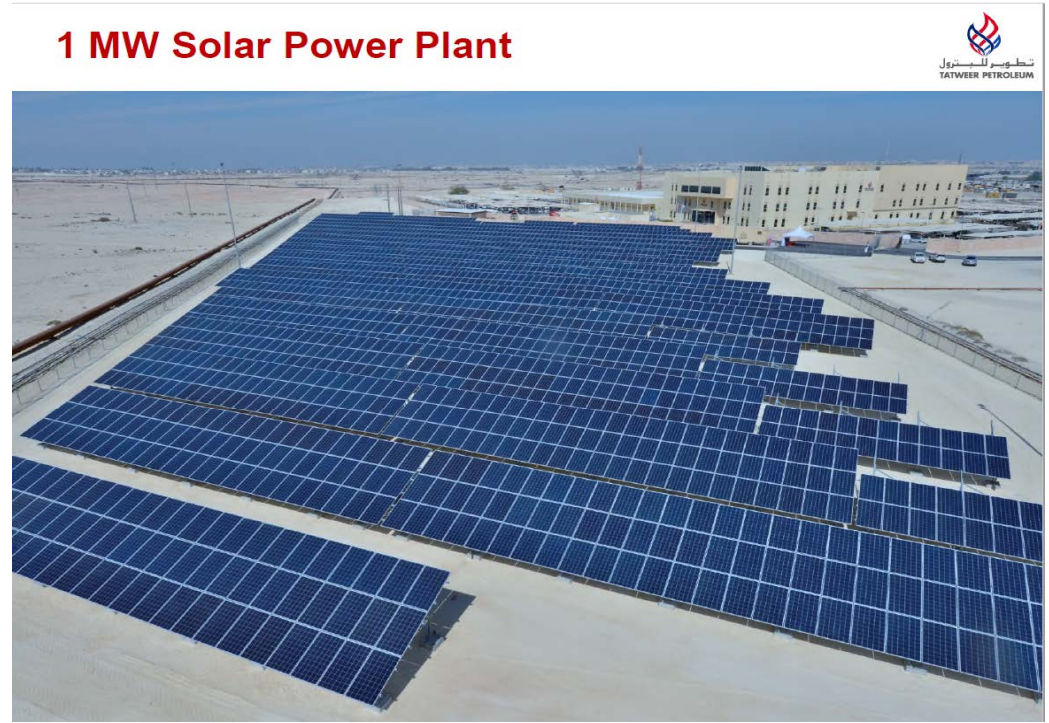

Figure 16. The $1 \mathrm{MW}$ polycrystalline PV installations in Bahrain by Tatweer Petroleum. The projected started operation in Operation since 2017. The efficiency of the PV panels is $15.4 \%$ with 16 invertors @ $60 \mathrm{kVA}$. The projected was constructed in 5 months only on a land of $14,900 \mathrm{~m}^{2}$ with PBP of 12 years.

Tatweer Petroleum in Bahrain has initiated 2 projects to utilize solar energy in the Bahrain Field: 1 MW Solar Power Plant (3980 polycrystalline PV panels having an efficiency of $15.4 \%$ with 16 invertors @ $60 \mathrm{kVA}$ on an area of 14,900 $\mathrm{m}^{2}$ ) which was completed and in operation since March 2016 (Figure 16). The other project is 2.3 MW Solar Power Plant (8064 single crystal PV panels having an efficiency of $15.4 \%$ with 28 invertors @ $100 \mathrm{kVA}$ on a land area of $50,000 \mathrm{~m}^{2}$ ) and it is under construction [29]. The PBP of the first project is 12 years and was constructed in 5 months only while the other has PBP of 9.25 years, will take 1 year for construction and will be completed in October 2019. The expected solar electricity gained annually is $5295 \mathrm{MWh}$. These two projects were inspired by the Bapco $5 \mathrm{MW}$ project and fulfilling the Bahrain Vision 2030. The $\mathrm{CO}_{2}$ energy saving in the first year of operation was $1.85 \mathrm{GWh}$-saving about 1800 tons of $\mathrm{CO}_{2}$.

\section{Conclusions}

Analysing the impact of Bapco 5 MW solar PV grid-connected project (completed in July 2014) on Bahrain's outlook for clean energy and energy-mix production, several positive impacts were counted. These impacts were on business, economy, environment, research, green jobs creation and rooftop installation and other large-scale installation in Bahrain.

Large and well-organized and planed projects attract public, investors and developers to invest in such projects, especially if the project is environmentally friendly and smart technology.

It is always necessary, prior to engaging in large projects, to conduct pilot innovated projects; in a similar trend made by Bapco. They had learnt from their 6 
kW solar, wind and hydrogen electrification for a lounge named as Alnakheel, it was the first zero emission lounge in Middle East in 2011 [30] [31]. After 2 years of such small project, Bapco had launched its innovative smart grid-connected 5 MW solar PV power plant that is enough to electrify 500 houses @ $10 \mathrm{~kW}$. Such important projects had inspired local universities to go green [32].

\section{Acknowledgements}

The authors thank the University of Bahrain for its moral and logistic support to conduct this study. The authors are grateful to Khaled Alnaser, Huda Al Banna, Samiya Shehab, Eng. Abdul Rahman Essam (Tatweer), Dr. Mohammed Al Othman (UoB), Prof Issa Batarseh (University of Central Florida), Eng. Adnan Al Othman (Bapco), Eng. Jassim AlSherawi (Bapco) for their technical assistance and kind cooperation.

\section{Conflicts of Interest}

The authors declare no conflicts of interest regarding the publication of this paper.

\section{References}

[1] Bahrain Center for Strategic, International and Energy Studies, Derasat (2019) Two Prosperous Decades. Miracles Publishing House, Manama. (In Arabic)

[2] https://www.bna.bh/en/.aspx?cms=q8FmFJgiscL2fwIzON1\%2bDjwonmDdvV\%2fw i\%2fZPLvjIQDw\%3d

[3] Abdulla, Y.A.G. and Bagdady, M.K. (1985) Global and Diffuse Solar Radiation in Doha (Qatar). Solar and Wind Technology, 2, 209-212. https://doi.org/10.1016/0741-983X(85)90018-9

[4] Alnaser, W.E. (1995) Renewable Energy Resources in the State of Bahrain. Applied Energy, 50, 23-30. https://doi.org/10.1016/0306-2619(95)90761-5

[5] Almarshoud, A.F. (2017) Technical and Economic Performance of 1 MW Grid-Connected PV System in Saudi Arabia. International Journal of Engineering Research and Applications, 7, 9-17. https://doi.org/10.9790/9622-0704010917

[6] Shiva Kumar, B. and Sudhakar, K. (2015) Performance Evaluation of 10 MW Grid Connected Solar Photovoltaic Power Plant in India. Energy Reports, 1, 184-192. https://doi.org/10.1016/j.egyr.2015.10.001

[7] Madiwal, P. and Reddy, L. (2014) Performance and Evaluation of 5 MW Grid Connected Solar PV Plant at Shivanasamudra. International Journal of Science \& Technology, 4, 11-16.

[8] Rehman, S. and El-Amin, I. (2012) Performance Evaluation of an Off-Grid Photovoltaic System in Saudi Arabia. Energy, 46, 451-458. https://doi.org/10.1016/j.energy.2012.08.004

[9] Alnaser, W.E., Alnaser, N.W. and Batarseh, I. (2014) Bahrain's Bapco 5 MW PV Grid-Connected Solar Project. International Journal of Power and Renewable Energy Systems, 1, 72-84.

[10] Batarseh, I. (2015) Distributed Smart Solar Technologies: Smart Cities of the Future [15-18 February 2015]. Renewable Energy for Sustainable Development, University of Bahrain, Zallaq. 
[11] https://books.google.com.bh/books?id=baQeBAAAQBAJ\&pg=PP1\&lpg=PP1\&dq= $\underline{\text { Slar}}+$ Home + design + Manual + Shawna + Henderson + and + Don + Roscoe\&source $=$ bl\& ots=Ej50rspKXr\&sig=ACfU3U3kvdvBxz23o3Jxjw7B_XY5jxlRKw\&hl=en\&sa=X\&ve $\mathrm{d}=2$ ahUKEwihovDYrozjAhWFwqYKHbNoC34Q6AEwDnoECAoQAQ\#v=onepage \&q=Solar\%20Home\%20design\%20Manual\%20Shawna\%20Henderson\%20and\%20 Don\%20Roscoe\&f=false

[12] Alnaser, N.W. (2009) Utilisation of Solar and Wind Energy in Buildings in the Kingdom of Bahrain: A Step towards Sustainable Building Construction. Ph.D. Thesis, University of Reading, Reading.

[13] Mekhile, S., Saidur, R. and Kamalisarvestani, M. (2012) Effect of Dust Humidity and Air Velocity on Efficiency of Photovoltaic Cells. Renewable \& Sustainable Energy Reviews, 16, 2920-2925. https://doi.org/10.1016/j.rser.2012.02.012

[14] Alnaser, W.E. and Alnaser, N.W. (2019) The Impact of the Rise of Using Solar Energy in GCC Countries. International Journal of Renewable Energy and Environmental Sustainability, 4, Article No. 7. https://doi.org/10.1051/rees/2019004

[15] Haji, S., Durazi, A. and Al-Alawi, Y. (2018) Feed-In Tariff Structure Development for Photovoltaic Electricity and the Associated Benefits for the Kingdom of Bahrain. International Journal of Sustainable Energy, 37, 1-16. https://doi.org/10.1080/14786451.2017.1304940

[16] https://www.worlddata.info/asia/bahrain/energy-consumption.php

[17] Alnaser, N.W., Al Othman, M.J., Dakhel, A.A., Batarseh, I., Lee, J.K., Najmaii, S., Alothman, A., Al Shawaikh, H. and Alnaser, W.E. (2018) Comparison between Performance of Man-Made and Naturally Cleaned PV Panels in a Middle of a Desert. Renewable \& Sustainable Energy Reviews, 82, 1048-1055. https://doi.org/10.1016/j.rser.2017.09.058

[18] Saidan, M., Albaali, A.G., Alasis, E. and Kaldellis, J. (2016) Experimental Study on the Effect of Dust Deposition on Solar Photovoltaic Panels in Desert Environment. Renewable Energy, 92, 499-505. https://doi.org/10.1016/j.renene.2016.02.031

[19] https://www.smart-energy.com/regional-news/africa-middle-east/bahrain-sustainab le-energy-unit

[20] http://iiict.uob.edu.bh/sites/it

[21] https://www.smartcities2019.com

[22] http://www.seu.gov.bh/nreap

[23] https://solarone.me

[24] Mas'ud, A.A., Wibra, A.V., Alshammari, S.J., Muhammad-Sukki, F., Abdullhadi, M., Albarracin, D. and Hoq, M.Z. (2018) Solar Energy Potentials and Benefits in the Gulf Cooperation Council Countries: A Review of Substantial Issues. Energies, 11, 372-392. https://doi.org/10.3390/en11020372

[25] https://www.utilities-me.com/power/12720-cover-feature-solar-champs

[26] Public Commission for the Protection of Marine Resources, Environment, and Wildlife (2012) Bahrain's Second National Communication-Under the United Nations Framework Convention on Climate Change. http://unfccc.int/resource/docs/natc/bhrnc2.pdf

[27] http://www.solarpowerworldonline.com/2013/04/what-are-the-advantages-of-ac-so lar-pv

[28] Kjaer, S.B., Pedersen, J.K. and Blaabjerg, F. (2005) A Review of Single-Phase Grid-Connected Inverters for Photovoltaic Modules. IEEE Transactions on Industry Applications, 41, 1292-1306. https://doi.org/10.1109/TIA.2005.853371 
[29] Tatweer Petroleum (2019) Solar Power in the Bahrain Oil Field. International Sustainable Energy Event 2019, Manama, 17-18 April 2019, Keynote Presentation.

[30] Alnaser, N.W. (2017) First Smart $8.64 \mathrm{~kW}$ BIPV in a Building in Awali Town at Kingdom of Bahrain. Renewable \& Sustainable Energy Reviews, 82, 205-214. https://doi.org/10.1016/j.rser.2017.09.041

[31] Haji, S., Bin Shams, M., Akbar, A.S., Abdali, H. and Alsaffar, A. (2019) Energy Analysis of Bahrain's First Hybrid Renewable Energy System. International Journal of Green Energy. https://doi.org/10.1080/15435075.2019.1619567

[32] Hamzah, R.Y., Alnaser, N.W. and Alnaser, W.E. (2018) Accelerating the Transformation to a Green University: University of Bahrain Experience. E3S Web of Conferences, 48, Article No. 06002. https://doi.org/10.1051/e3sconf/20184806002 